\title{
The giant Zaozigou Au-Sb deposit in West Qinling, China: magmatic- or metamorphic-hydrothermal origin?
} KUNFENG QIU $^{12}$, HAOCHENG YU $^{1}$, DUNCAN MCINTIRE
,
ZHAOSHAN CHANG

${ }^{1}$ China University of Geosciences, Beijing 100083, China, Kunfengqiu@qq.com

${ }^{2}$ School of Mines, Golden, CO 80401, USA

Understanding the relationship between mineral occurrences and host granitic rocks can be controversial. The Zaozigou Au-Sb deposit (118 t Au, 0.12Mt Sb), hosted in metasedimentary rocks and dacitic to granodioritic sills and dikes, is one such example of a large gold deposit argued to have formed from either magmatic or metamorphic hydrothermal processes. Two populations of monazite are identified within a mineralized dacite located along a major shear zone. Magmatic monazite commonly occurs within magmatic biotite and quartz phenocrysts and is characterized by uniform and high Th concentrations. It has a crystallization age of $238.3 \pm 2.6 \mathrm{Ma}$, consistent with the zircon $\mathrm{U}-\mathrm{Pb}$ age of $238.0 \pm 1.8 \mathrm{Ma}$ from the same dacite. Hydrothermal monazite is associated with sulfides and sericite, and has a ${ }^{207} \mathrm{~Pb}$-corrected ${ }^{206} \mathrm{~Pb} /{ }^{238} \mathrm{U}$ age of $211.1 \pm$ 3.0 Ma. The amount of Th in hydrothermal monazite is widely variable. The low Th content of some monazite grains reflects direct precipitation from a metamorphic hydrothermal fluid. Furthermore, the elevated Th content in other hydrothermal monazite grains is likely due to the release of Th (and U) into hydrothermal fluids by dissolution of preexisting Th-rich minerals in the country rock during orerelated alteration events. The magmatism, which overlaps Middle-Late Triassic terrane subduction-accretion in theWest Qinling orogen, thus pre-dates the ore-forming event by about 30 m.y. The $\delta^{34} \mathrm{~S}$ values of pyrite, arsenopyrite, stibnite, marcasite, and chalcopyrite from disseminated- and vein-type ores range from -12.0 to $-5.5 \%$. Such negative values are distinct from those measured for other deposits in the northwestern part of the orogen that are genetically related to Triassic magmatism, including the Xiekeng-JiangligouShuangpengxi $\mathrm{Cu}-\mathrm{Au}-\mathrm{Fe}-\mathrm{Mo}$ skarn, Laodou reduced intrusion-related $\mathrm{Au}$, and Gangcha epithermal $\mathrm{Au}$ ores. The Zaozigou deposit is best classified as an epizonal orogenic $\mathrm{Au}-\mathrm{Sb}$ deposit. Our results demonstrate the usefulness of high-precision in situ geochronology on monazite for deciphering age relationships in ore deposits that have spatial associations with granitic rocks, thus aiding in the testing of the veracity of ore formation models. 